\title{
PRAKTIK KEWIRAUSAHAAN GEREJA: Upaya Gereja Pentakosta dalam Mengentaskan Kemiskinan di Kota Wamena
}

\author{
Mika Daddu Ngedi \\ Sekolah Tinggi Teologi Arastamar Wamena \\ mikadngedi@gmail.com
}

\begin{abstract}
This study aims to examine and describe entrepreneurial practices of the Pentecostal church in alleviating poverty in Wamena. The method in this research is an explanatory sequential mixed method which firstly conducts quantitative research, analyzes the results and then arranges the results to explain them more details with qualitative research. The sample is GPdI Elshaddai Wamena and GPdl Elroi Wamena purposively selected, namely the congregations who did entrepreneurship practices. Data collection techniques are through questionnaires, observation, and interviews. Data is collected and analyzed quantitatively, through the relative frequency distribution table, and described qualitatively.

The results showed $132 \mathrm{GPdl}$ Elshaddai Wamena congregations and $156 \mathrm{GPdl}$ Elroi Wamena congregations had practiced entrepreneurship in the church well. Entrepreunership practices carried out by GPdl Elshaddai Wamena and GPdl Elroi Wamena that have contributed to alleviating poverty in Wamena.
\end{abstract}

Keywords: entrepreneurship, poverty

Abstrak: Penelitian ini bertujuan untuk mengkaji dan mendeskripsikan praktik-praktik kewirausahaan gereja beraliran pentakostal dalam mengentaskan kemiskinan di Kota Wamena. Metode penelitian yang digunakan adalah metode campuran sekuensial eksplanatori yakni metode di mana peneliti terlebih dahulu melakukan penelitian kuantitatif, menganalisis hasil dan kemudian menyusun hasil untuk menerangkannya secara lebih terperinci dengan penelitian kualitatif. Sampel dalam penelitian ini adalah GPdl Elshaddai Wamena dan GPdl Elroi Wamena yang dipilih secara purposif yakni jemaat yang melakukan praktik kewirausahaan. Teknik pengumpulan data yang dilakukan adalah melalui angket, observasi dan wawancara. Data yang telah terkumpul kemudian dianalisis secara kuantitatif yakni melalui tabel distribusi frekuensi relatif, dan selanjutnya dideskripsikan secara kualitatif.

Hasil penelitian menunjukkan bahwa ada 132 orang jemaat GPdi Elshaddai Wamena dan 156 orang jemaat GPdl Elroi Wamena telah melakukan praktik kewirausahaan dalam jemaat dengan baik. Praktik-praktik kewirausahan yang dilakukan oleh GPdi Elshaddai Wamena dan GPdl Elroi Wamena telah berkontribusi dalam mengentaskan kemiskinan di Kota Wamena.

Kata Kunci: kewirausahaan, kemiskinan

Kemiskinan merupakan salah satu isu yang terus up to date, walaupun kemiskinan sudah terjadi sejak zaman dahulu kala. Dikatakan up to date, karena persoalan tentang kemiskinan tidak pernah bisa diberantas atau ditanggulangi secara tuntas. Di mana ada manusia di situ pasti ada kemiskinan. Sebagaimana dikemukakan oleh Wahyu (2009) bahwa "masa- 
lah kemiskinan sebagai persoalan yang sangat asasi, tumbuh dan berkembang seusia manusia itu sendiri." Sementara menurut Alkitab, kemiskinan itu mulai ada sejak manusia jatuh ke dalam dosa. Di mana, sebelum jatuh ke dalam dosa manusia di dalam taman Eden hidup dalam kelimpahan (bnd. Kej 2). Setelah jatuh ke dalam dosa, manusia harus bersusah payah dan berpeluh mencari makanannya (bnd. Kej. 3: 17-19). Artinya, untuk dapat bertahan hidup manusia harus bekerja keras dan sebaliknya jika tidak bekerja keras pasti akan hidup dalam kekurangan dan kelaparan. Selanjutnya, di dalam Perjanjian lama, kemiskinan juga dideskripsikan dalam keluaran 23:6, 11, Imamat 24:17, dan kisah tentang janda miskin di Sarfat (I Raja 17:7-24). Sementara di dalam Perjanjian Baru, kemiskinan digambarkan sebagai keadaan yang berkekurangan secara fisik, ekonomi, sosial, politik dan agama (bnd. Luk. 4:18-19; 7:22).

Hingga kini, persoalan kemiskinan masih terus terjadi. Dengan kata lain, kemiskinan itu dapat terjadi di mana saja pada lintas masa dan generasi hingga saat ini, baik di negara berkembang maupun di negara maju. Indonesia sebagai salah satu negara berkembang tidak luput dari persoalan kemiskinan, di mana terjadi hampir di seantero daerah di Indonesia dan tidak terkecuali kabupaten Jayawijaya, Papua. Menurut Berita Resmi Statistik (BPS Propinsi Papua, 2018), persentase penduduk miskin periode September 2017 - Maret 2018 berdasarkan provinsi, Papua berada pada urutan 33 dengan persentase angka kemiskinan 27.74\%, dan Papua Barat berada pada urutan 34 dengan persentase angka kemiskinan $23.01 \%$ dari total 34 Provinsi di Indonesia. Sedang- 
kan Data Badan Pusat Statistik Kabupaten Jayawijaya (BPS Kabupaten Jayawijaya, 2018) menyatakan bahwa data jumlah penduduk miskin menurut kabupaten, Jayawijaya berada pada angka $81.94 \%$ jumlah penduduk miskin pada tahun 2018. Walupun berbagai upaya telah dilakukan oleh pemerintah seperti Bantuan Beras Miskin, Bantuan Langsung Tunai (BLT) hingga bantuan Dana Otonomi Khusus, namun angka kemiskinan tetap tinggi. Hanya dikabarkan bahwa pada periode September 2017-Maret 2018 angka kemiskinan di Provinsi Papua turun $0.02 \%$ dibandingkan dengan periode sebelumnya.

Berdasarkan hasil observasi peneliti yang sekaligus sebagai pelaku usaha kecil di Kota Wamena sejak 2016-2019, tingginya angka kemiskinan di Kabupaten Jayawijaya salah satunya dipengaruhi oleh faktor ekonomi misalnya tingginya harga-harga bahan kebutuhan pokok dan kebutuhan lainnya sangat berpengaruh terhadap daya beli masyarakat. Hal ini dapat dilihat dari harga-harga bahan kebutuhan pokok yang ada di Kota Wamena ( seperti; harga beras Bulog $50 \mathrm{Kg}$ sebesar Rp. 800.000-, s.d Rp. 950.000., per Karung, harga beras Betet, beras merk 99 dan beras bersih lainnya yang berukuran $25 \mathrm{~kg}$ sebesar Rp. 545.000-, s.d. Rp. 565.000-, harga minyak goreng bimoli berukuran 5 liter sebesar Rp. 120.000-, s.d. Rp. 135.000-, harga gula pasir per karung dengan berat 50 kg sebesar Rp. 1.200.000-, s.d. Rp. 1.300.000-, dan beberapa harga bahan pokok dan harga kebutuhan lainnya seperti; harga telur ayam ras per rak sebesar Rp. 75.000-, s.d. Rp. 95.000-, harga semen per sak adalah Rp. 530.000-,. dan lain-lain. Tingginya harga bahan kebutuhan pokok dan kebutuhan lainnya berbanding terbalik 
dengan tingkat pendapatan masyarakat. Misalnya; gaji pokok Pegawai Negeri Sipil golongan II dan III hanya berkisar antara Rp. 1.500.000-, s.d. Rp. 3.500.000-, .

Kemiskinan secara umum sering dipahami sebagai kekurangan, terutama kekurangan bahan pokok, seperti; pangan, sandang, papan dan kesehatan. Dengan kata lain, kemiskinan merupakan ketidakmampuan memenuhi kebutuhan pokok sehingga seseorang mengalami keresahan, kesengsaraan dan kemelaratan. Akan tetapi, persoalan kemiskinan tidak hanya selalu berkaitan dengan masalah ekonomi, tetapi juga merupakan masalah politik, sosial, budaya dan sebagainya. Menurut Syaiful IImi, "kemiskinan bukan saja berurusan dengan persoalan ekonomi belaka, melainkan juga bersifat multidimensional karena dalam kenyataannya juga berurusan dengan persoalan-persoalan non ekonomi, sosial, budaya dan politik. Karena sebab multidimensional tersebut, maka kemiskinan tidak hanya berurusan dengan kesejahteraan sosial (social well-being) saja, akan tetapi lebih dari itu" (Ilmi, 2018). Oleh karena persoalan kemiskinan bersifat multidimensional, maka upaya penanganan atau penanggulangannyapun harus bersifat holistik. Pertanyaan adalah, siapa yang paling bertanggung jawab terhadap masalah kemiskinan tersebut? Bagaimana cara mengentaskan atau menanggulanginya. Cukup banyak penelitian yang telah dilakukan berkaitan dengan masalah kemiskinan dan upaya-upaya pengentasannya. Penelitian-penelitian tersebut di antaranya:

1. Penelitian yang dilakukan oleh Simon Julianto (2017)), di mana salah satu fokus penelitiannya tentang praktik kewirausahaan jemaat dewasa 
ini yakni di Gereja Kristen Jawa (GKJ). Beberapa praktik kewirausahaan GKJ yang dilaksanakan pada aras sinode yaitu: (1) Dana Abadi Sinode yang diperuntukkan bagi (a) peningkatan kapitalisasi Dana Pensiun GKJ; (b) membantu jemaat-jemaat yang tidak mampu memanggil pendeta; (c) dana bantuan biaya hidup tenaga GKJ; (d) perkreditan perumahan gereja, biaya studi anak peserta dana pensiun GKJ; (e) biaya studi lanjut, peningkatan kemampuan pendeta, dan lain-lain; (2) Mendirikan PT Rumeska Mekaring Sabda; (3) Membentuk unit-unit usaha yang dikelola oleh kantor sinode GKJ; (4) Kewirausahaan di lingkungan gereja-gereja Kristen Jawa pada aras Klasis maupun jemaat Lokal.

2. Penelitian yang dilakukan oleh Fibry Jati Nugroho (2019) yang memfokuskan pada beberapa kajian di antaranya: Pertama, Peranan Gereja di Tengah Kemiksinan bahwa gereja tidak bisa melepaskan diri dari persoalan kemiskinan yang sedang dihadapi. Justru panggilan gereja adalah terlibat secara aktif dalam memerangi kemiskinan dan ketidakadilan; Kedua, Pemberdayaan Jemaat Sebagai Alternatif Solusi, bahwa jemaat tidak hanya mendapatkan ajaran dan ujaran dari sang pembawa Firman tetapi juga dapat diberdayakan untuk dapat berdikari. Tugas holistik gereja menjadi lengkap ketika memasukkan pemberdayaan di dalam fungsi pastoralnya; Ketiga, Pandangan Kaum Evangelikal tentang Kemiskinan, di mana kaum evangelikal sangat peduli untuk memberi sumbangsih, baik dalam pemikiran teologis, maupun dari sisi praksisnya. 
3. Penelitian yang dilakukan oleh Risviantika dkk. (2017) melalui pendekatan strength. Tujuan dari tulisan ini adalah untuk memberikan alternatif pemecahan masalah kemiskinan melalui kewirausahaan sosial dengan pendekatan strenght perspektif dalam pandangan ilmu kesejahteraan sosial. Pendekatan strenght adalah salah satu pendekatan dalam ilmu kesejahteraan sosial yang melihat berbagai masalah bukan dari kekurangan yang dimiliki baik oleh individu, kelompok atau masyarakat tetapi melihat dari kekuatan yang dimilikinya. Kewirausahaan dalam pandangan strength diartikan sebagai upaya untuk membuka peluang-peluang ekonomi yang dimiliki oleh masyarakat miskin dengan kekuatan atau sumber daya yang dimilikinya sebagai upaya untuk mengurangi atau lepas dari kemiskinan.

4. Penelitian yang dilakukan oleh Malik dan Mulyono (2017). Tujuan dari penelitian ini adalah mendeskripsikan pengembangan kewirausahaan berbasis potensi lokal melalui pemberdayaan masyarakat yang terdiri dari beberapa tahapan di antaranya pelatihan, proses produksi dan pemasaran serta kendala yang dialami.

5. Penelitian yang dilakukan oleh Sukirman (2017). Tujuan dalam penelitian ini adalah untuk memberi bukti empiris sejauh mana jiwa dan nilai kewirausahaan mempengaruhi terbentuknya kemandirian usaha dari aspek jiwa kewirausahaan, nilai kewirausahaan, perilaku kewirausahaan dan kemandirian usaha.

6. Penelitian yang dilakukan oleh Erlangga Agustino Landyanto (2014) yang memfokuskan pada identifikasi peluang dan perumusan strategi 
bagi pengembangan keuangan mikro untuk mendukung pengentasan kemiskinan dan pemberdayaan ekonomi rakyat Papua. Penguatan keuangan mikro di Papua dapat dilakukan dengan beberapa cara, antara lain adalah dengan penguatan kapasitas lembaga keuangan mikro (LKM), pendirian lembaga Apex bagi LKM, pemberian kredit bersubsidi, chaneling maupun adanya lembaga penjaminan kredit. Selain itu, perlu dibangun keuangan mikro berbasis komunitas baik dengan pembentukan dan penguatan kelompok swadaya masyarakat (KSM), group lending yang didukung dengan penguatan lembaga pendamping UKM melalui pelatihan maupun lembaga payung.

Dari penelitian dan kajian-kajian tersebut dapat disimpulkan bahwa ada banyak cara atau upaya dalam pengentasan kemiskinan, melalui pendekatan karakteristik penduduk miskin, pengembangan keuangan mikro, rekonstruksi teologi kemiskinan, membangun kesadaran kolektf dan membangun etos kerja individu serta kewirausahaan jemaat baik pada aras sinode maupun pada aras klasis dan jemaat lokal. Selain itu, permasalahan kemiskinan bukanlah tanggung jawab satu pihak, satu kelompok/komunitas tertentu saja tetapi tanggung jawab semua pihak. Baik pemerintah pusat, pemerintah daerah, masyarakat dan dunia kerja serta dunia usaha bahkan gereja.

Berbeda dengan penelitian-penelitian yang telah disebutkan sebelumnya, penelitian ini difokuskan pada praktik kewirausahaan di gereja-gereja pentakosta. Berdasarkan pengamatan peneliti sebagai salah satu jemaat gereja 
pentakosta, beberapa alasan mengapa penelitian ini berfokus pada gereja-gereja pentakosta: Pertama, gereja-gereja pentakosta pada satu sisi menjadikan gereja layaknya "lahan bisnis guna meraup keuntungan," akan tetapi pada sisi yang lain gereja-gereja pentakosta masih "alergi" terhadap kata "kewirausahaan, berwirausaha dan bisnis, di mana mereka menganggap bahwa kata-kata tersebut hanya berkaitan dengan orang-orang sekuler yang memiliki jiwa usaha dan bisnis. Selain itu, "kewirausahaan, berwirausaha dan bisnis" dianggap sebagai sebuah pekerjaan duniawi; Kedua, gereja-gereja pentakosta lebih fokus pada kegiatan membangun "kerajaan" sendiri, seperti membangun gedung gereja yang megah yang dilengkapi dengan alat musik dan asesoris yang mahal, tetapi menutup mata dan telinga terhadap pergumulanpergumulan yang dihadapi dan dialami oleh sesama jemaat secara internal walaupun sering melakukan pelayanan diakonia atau pelayanan sosial; Ketiga, gereja-gereja pentakosta secara sadar tahu bahwa tingkat kebutuhan hidup di Kota Wamena sangat tinggi yang berpengaruh terhadap daya beli jemaat karena tidak seimbang dengan pendapatan mereka; maka seyogianya pelayanan diakonia harus terlebih dahulu difokuskan secara internal dan memiliki langkah-langkah solutif dalam memberdayakan jemaat agar mandiri secara ekonomi, di mana juga akan berdampak pada kemandirian gereja sebagai organisasi dari sisi aset dan finansial.

Kabupaten Jayawijaya sebagai salah satu daerah mayoritas Kristen, sudah sepatutnya gereja-gereja terlibat aktif dan berupaya dalam memberdayakan jemaat agar tidak terjerumus ke dalam persoalan 
kemiskinan yang berkepanjangan. Salah satu upaya yang dilakukan oleh gereja adalah mendorong dan memberdayakan jemaat agar memiliki jiwa kewirausahaan yang dibuktikan melalui praktik kewirausahaan.

Kewirausahaan menurut Instruksi Presiden RI Nomor 4 Tahun 1995 adalah semangat, sikap perilaku, dan kemampuan seseorang dalam menangani usaha dan atau kegiatan yang mengarah pada upaya mencari, menciptakan dan menerapkan cara kerja, teknologi dan produk baru dengan meningkatkan efisiensi dalam rangka memberikan pelayanan yang lebih baik dan atau memperoleh keuntungan yang lebih besar. Sementara praktik kewira -usahaan dilakukan melalui usaha kecil/mikro yang dilakukan oleh seseorang yang memiliki semangat dan kemampuan dalam menangani usahanya. Usaha kecil/mikro sebagaimana menurut Keputusan Menteri Keuangan No. 40/KMK.06/2003 tanggal 29 Januari 2003, yaitu usaha produktif miliki keluarga atau perorangan Warga Negara Indonesia dan memiliki hasil penjualan paling banyak Rp. 100.000.000-, (seratus juta rupiah) per tahun. Usaha mikro dapat mengajukan kredit kepada bank paling banyak Rp. 50.000.000-, (lima puluh juta rupiah). Jenis usaha mikro antara lain: (1) dagang/industri makanan dan minuman seperti warung kelontong, warung nasi, mie bakso, sayuran, jamu; (2) industri kecil seperti; konveksi, pembuatan tempe/kerupuk/kecap/kompor/ sablon; (3) jasa seperti; tukang cukur, tambal ban, bengkel motor, tukang las, penjahit; (4) pengrajin seperti; sabuk, tas, cindera mata, perkayuan, anyaman; (5) industri meubelair pengolahan kayu dan rotan, industri pandai besi pembuat alat-alat; (6) pertanian/peternakan dan perikanan; (7) usaha perdagangan seperti kaki lima, serta pedagang di pasar dan lain-lain; (8) usaha jasa-jasa seperti perbengkelan, salon kecantikan, ojek dan penjahit. 
Berdasarkan latar belakang permasalahan di atas, penelitian ini bertujuan untuk mengkaji dan mendeskripsikan praktik kewirausahaan gereja-gereja pentakosta sebagai salah satu upaya dalam mengentaskan kemiskinan di Kota Wamena.

\section{METODE}

Metode penelitian yang digunakan adalah metode campuran sekuensial eksplanatori (explanatory sequential mixed methods) yakni metode di mana peneliti terlebih dahulu melakukan penelitian kuantitatif, menganalisis hasil dan kemudian menyusun hasil untuk menerangkannya secara lebih terperinci dengan penelitian kualitatif (Creswell, 2016). Sampel dalam penelitian ini adalah GPdl Elshaddai Wamena dan GPdl Elroi Wamena yang dipilih secara purposif yakni peneliti memilih dan menentukan sumber data berdasarkan pertimbangan-pertimbangan tertentu (Purwanto, Erwan, \& Sulastyastusi, 2007) yaitu; jemaat yang merupakan pelaku dari praktik kewirausahaan dan juga gembala jemaat sebagai orang yang bertanggung jawab terhadap pelayanan dan keberadaan jemaat.

Teknik pengumpulan data yang dilakukan adalah melalui angket, observasi dan wawancara. Data yang telah terkumpul kemudian dianalisis secara kuantitatif yakni melalui analisis statistik deskriptif. Menurut Sudijono (2010), analisis deskriptif ini dilakukan dengan caracara penyajian dalam bentuk tabel distribusi frekuensi relatif: suatu keadaan yang menggambarkan bagaimana frekuensi atau gejala dari variabel yang dilambangkan dengan angka-angka itu, telah tersalur, terbagi 
atau terpencar. Untuk mencari nilai persentasenya digunakan rumus:

$$
P=F \times 100 \% \text {. }
$$

$\mathrm{N}$

Keterangan:

$$
\begin{aligned}
& \text { P: Persentase } \\
& \text { F: Frekuensi (responden yang menjawab) } \\
& \text { N: Total responden }
\end{aligned}
$$

Selanjutnya hasil analisis kuantitatif dideskripsikan secara kualitatif.

\section{HASIL}

Praktik-praktik kewirausahaan dalam jemaat GPdl Elshaddai Wamena dan GPdI Elroi Wamena dapat dideskripsikan sebagai berikut:

\section{Jemaat GPdI Elshaddai Wamena}

Praktik-praktik kewirausahaan dalam jemaat GPdl Elshaddai Wamena meliputi; (1) dagang/industri makanan dan minuman yaitu warung kelontong, warung nasi, mie bakso, sayuran, jamu; (2) jasa seperti; tambal ban, bengkel motor, tukang las, penjahit; (3) pengrajin yaitu perkayuan; (4) pertanian/peternakan dan perikanan; (5) usaha perdagangan seperti kaki lima, serta pedagang di pasar dan lain-lain; (6) usaha jasa-jasa seperti perbengkelan, salon kecantikan, ojek dan penjahit. Adapun pelaku-pelaku kewirausahaan dalam jemaat GPdi Elshaddai Wamena dapat dilihat pada Tabel 1.

Data pada Tabel 1 menunjukkan bahwa orang ada 132 jemaat GPdl Elshaddai Wamena yang melakukan praktik kewirausahaan yang terdiri dari 30 orang jemaat atau $22.72 \%$ yang melakukan usaha warung 
kelontong, warung nasi 5 orang (3.78\%), mie bakso 3 orang $(2.27 \%)$, sayuran 3 orang (2.27), tambal ban 2 orang (1.51\%), perbengkelan 2 orang $(1.51 \%)$, tukang las 7 orang $(5.30 \%)$, penjahit 2 orang $(1.51 \%)$, perkayuan 15 orang (11.36\%), pertanian 3 orang $(2.27 \%)$, peternakan 25 orang (18.93\%), kaki lima 5 orang (3.78\%), pedagang di pasar 7 orang (5.30\%), salon kecantikan 3 orang $(2.27 \%)$ dan tukang ojek 20 orang $(15.15 \%)$.

Tabel 1. Data Pelaku Kewirausahaan GPdi Elshaddai Wamena yaitu:

\begin{tabular}{llcc}
\hline No & Jenis Usaha & Frekuensi & Persentase \\
\hline 1 & Warung Kelontong & 30 & $22.72 \%$ \\
2 & Warung Nasi & 5 & $3.78 \%$ \\
3 & Mie Bakso & 3 & $2.27 \%$ \\
4 & Sayuran & 3 & $2.27 \%$ \\
5 & Tambal Ban & 2 & $1.51 \%$ \\
6 & Bengkel Motor/Mobil & 2 & $1.51 \%$ \\
7 & Tukang Las & 7 & $5.30 \%$ \\
8 & Penjahit & 2 & $1.51 \%$ \\
9 & Perkayuan & 15 & $11.36 \%$ \\
10 & Pertanian & 3 & $2.27 \%$ \\
11 & Peternakan & 25 & $18.93 \%$ \\
12 & Kaki Lima & 5 & $3.78 \%$ \\
13 & Pedagang di Pasar & 7 & $5.30 \%$ \\
14 & Salon Kecantikan & 3 & $2.27 \%$ \\
15 & Ojek & 20 & $15.15 \%$ \\
\hline
\end{tabular}

\section{Jemaat GPdI EIRoi Wamena}

Praktik-praktik kewirausahaan dalam jemaat GPdl Elroi Wamena di antaranya; (1) dagang/industri makanan dan minuman yaitu warung kelontong, warung nasi, mie bakso, sayuran, jamu; (2) jasa seperti; tam- 
bal ban, bengkel motor, tukang las, penjahit; (3) pengrajin yaitu perkayuan; (4) pertanian/peternakan dan perikanan; (5) usaha perdagangan seperti kaki lima, serta pedagang di pasar dan lain-lain; (6) usaha jasa-jasa seperti perbengkelan, salon kecantikan, ojek dan penjahit.

Tabel 2. Data Pelaku Kewirausahaan Jemaat GPdl Elroi Wamena

\begin{tabular}{clcc}
\hline No & \multicolumn{1}{c}{ Jenis Usaha } & Frekuensi & Persentase \\
\hline 1 & Warung Kelontong & 30 & $19.23 \%$ \\
2 & Warung Nasi & 3 & $1.92 \%$ \\
3 & Mie Bakso & 3 & $1.92 \%$ \\
4 & Sayuran & 3 & $1.92 \%$ \\
5 & Tambal Ban & 7 & $4.48 \%$ \\
6 & Bengkel Motor/Mobil & 9 & $5.76 \%$ \\
7 & Tukang Las & 9 & $5.76 \%$ \\
8 & Penjahit & 2 & $1.28 \%$ \\
9 & Perkayuan & 20 & $12.82 \%$ \\
10 & Pertanian & 3 & $1.92 \%$ \\
11 & Peternakan & 35 & $22.43 \%$ \\
12 & Kaki Lima & 7 & $4.48 \%$ \\
13 & Pedagang di Pasar & 5 & $3.20 \%$ \\
14 & Salon Kecantikan & 3 & $1.92 \%$ \\
15 & Ojek & 17 & $10.89 \%$ \\
\hline
\end{tabular}

Tabel di atas menunjukkan bahwa orang ada 156 jemaat GPdl Elshaddai Wamena yang melakukan praktik kewirausahaan yang terdiri dari 30 orang jemaat atau $19.23 \%$ yang melakukan usaha warung kelontong, warung nasi 3 orang (1.92\%), mie bakso 3 orang (1.92\%), sayuran 3 orang (1.92), tambal ban 7 orang (4.48\%), perbengkelan 9 orang $(5.76 \%)$, tukang las 9 orang $(5.76 \%)$, penjahit 2 orang $(1.28 \%)$, 
perkayuan 20 orang $(12.82 \%)$, pertanian 3 orang $(1.92 \%)$, peternakan 35 orang $(22.43 \%)$, kaki lima 7 orang $(4.48 \%)$, pedagang di pasar 5 orang (3.20\%), salon kecantikan 3 orang (1.92\%) dan tukang ojek 17 orang $(10.89 \%)$.

\section{PEMBAHASAN}

Dari hasil penelitian di atas, dapat dikatan baik GPdI Elshaddai Wamena maupun GPdl Elroi Wamena dapat berkontribusi dalam mengentaskan kemiskinan di Kota Wamena. Kontribusi tersebut dapat dijelaskan melalui dua hal: Pertama, persamaan GPdI Elshaddai Wamena dan GPdl Elroi Wamena adalah sama-sama memiliki jiwa kewirausahaan yang tinggi dan diaplikasikan melalui praktik-praktik kewirausahaan. Jiwa kewirausahaan, menurut Hartanti dalam Sukirman (2017), merupakan nyawa kehidupan dalam kewirausahaan yang pada prinsipnya merupakan sikap dan perilaku kewirausahaan dengan ditunjukkan melalui sifat, karakter dan watak seseorang yang memiliki kemauan dalam mewujudkan gagasan inovatif ke dalam dunia nyata secara kreatif. Menurut Kuratko Sukirman (2017), jiwa kewira-usahaan meliputi kepribadian yang memiliki tindakan kreatif sebagai nilai, gemar berusaha, tegar dalam berbagai tantangan, percaya diri, memiliki self determintatio, berkemampuan mengelola resiko, perubahan dipan-dang sebagai peluang, toleransi terhadap banyaknya pilihan, inisiatif dan memiliki need for achievement, perfeksionis, berpandangan luas, meng-anggap waktu sangat berharga serta memiliki motivasi yang kuat, dan karakter itu telah menginternalisasi sebagai nilai-nilai yang diyakini benar. 
Berdasarkan hasil wawancara dengan beberapa jemaat dari kedua gereja tersebut menunjukkan praktik kewirausahaan dibangun dan dibentuk oleh keadaan. Keadaan yang dimaksud adalah tingginya hargaharga kebutuhan pokok dan harga kebutuhan lainnya di kota Wamena. Keadaan inilah yang membentuk pola pikir, semangat kerja keras dari para jemaat. Sebagaimana dikemukakan oleh salah satu jemaat yang berinisial "AS" hari jumat tanggal 3 Mei 2019 bahwa "berwirausaha apalagi dalam konteks Wamena mutlak dibangun dan dipupuk untuk dapat memenuhi segala kebutuhan hidup. Jika tidak demikian, maka pasti akan berada dalam keadaan kemiskinan yang berkepanjangan."

Kedua, Perbedaan antara Jemaat jemaat GPdl Elshaddai Wamena dengan GPdI Elroi Wamena dalam melakukan praktik-praktik kewirausahaan. Jemaat GPdI Elshaddai memiliki jiwa dan praktik-praktik kewirausahaan, dibangun dan dibentuk oleh keadaan dan kesadaran jemaat sendiri. Sedangkan Jemaat GPdl Elroi Wamena, selain memiliki jiwa dan praktik-praktik kewirausahaan yang dibangun dan dibentuk oleh keadaan dan kesadaran jemaat sendiri, juga dibentuk oleh peranan gembala yang sangat besar. Salah satu jemaat GPdl Elroi yaitu "S" yang berhasil diwawancarai menyatakan bahwa mereka boleh eksis dalam praktik-praktik kewirausahaan karena dukungan penuh dari gembala jemaat, baik dalam bentuk semangat maupun materi dan dana. Hal senada dikemukakan oleh gembala jemaat Pdt. Gideon Widiono pada tanggal 7 Mei 2019 yang berkata "saya sebagai gembala, sangat konsen dalam mengembalakan jemaat bukan saja berkaitan dengan hal-hal rohani tetapi juga hal-hal jasmani”. Lebih lanjut pendeta Gideon berkata: 
"untuk hal-hal yang bersifat jasmani, selaku gembala jemaat dengan memperhatikan biaya hidup yang begitu tinggi di Kota Wamena, saya selalu mendorong jemaat untuk berwirausaha. Mengapa? Karena peluang usaha sangat besar. Selain itu, saya tidak hanya sekedar mendorong jemaat hanya karena ada peluang usaha semata-mata, tanpa tindakan nyata. Saya langsung membantu jemaat dalam bentuk modal usaha, tempat usaha dan alat-alat untuk berusaha. Misalnya' memberikan uang untuk membuka usaha bagi yang sudah memiliki tempat usaha. Sedangkan bagi yang belum memiliki tempat usaha, saya memberikan tempat usaha seperti ruko. Selain itu, saya juga memberikan motor bagi jemaat yang mau ojek." Lebih lanjut lagi pendeta Gideon berkata: "sebenarnya masih banyak hal yang saya selaku gembala lakukan untuk jemaat. Tidak hanya berkaitan dengan usaha kecil tetapi juga berkaitan dengan urusan-urusan lainnya seperti membuat seminar tentang kewirausahaan, turut langsung mengedukasi masyarakat tentang pentingnya berwirausaha, membantu jemaat dalam hal pengurusan SIM, KTP, Akta Kelahiran dan sebagainya di mana gereja bekerja sama dengan instansi-instansi terkait dan juga membangun sekolah PAUD-TK, SD dan SMP yang saat ini sudah memiliki ijin pendirian dari Dinas Pendidikan."

Selain persamaan dan perbedaan antara kedua gereja di atas, dalam hubungannya dengan praktik-praktik kewirausahaan dalam jemaat, GPdl Elroi dan GPdl Elshaddai Wamena juga telah mengembangkan pelayanan terhadap masalah kemiskinan di antaranya melalui pelayanan diakonia dan pelayanan sosial lainnya. GPdl Elroi dan GPdl 
Elshaddai Wamena sangat peduli pelayanan terhadap kaum marginal, miskin dan terbelakang. Pelayanan ini dilakukan secara berkala bukan saja di seputaran kota Wamena, tetapi juga di pinggir kota hingga di luar kota dan bahkan di kampung-kampung yang berada di balik gunung di Kabupaten Jayawijaya dan Kabupaten lainnya di Pegunungan Tengah Papua. Bentuk kepedulian bermacam-macam, seperti; pelayanan kaum wanita, pelayanan pemuda, bantuan bahan kebutuhan pokok, membangun sekolah dan tempat-tempat ibadah. Semua pelayanan dimaksud dapat berjalan dengan baik, tidak terlepas dari dukungan jemaat terutama dari sisi materi dan finansial.

\section{KESIMPULAN}

Berdasarkan hasil penelitian di atas, dapat disimpulkan bahwa praktik kewirausahaan gereja-gereja pentakosta yakni GPdl Elshaddai Wamena dan GPdl Elroi Wamena telah berkontribusi terhadap upaya pengentasan kemiskinan di kota Wamena, yaitu: pertama, jemaat GPdl Elshaddai Wamena yang melakukan praktik kewirausahaan berjumlah 132 orang dan GPdl Elroi Wamena berjumlah 156 orang melalui jenis usaha warung kelontong, warung nasi, mie bakso, sayuran, tambal ban, bengkel motor, tukang las, penjahit, perkayuan; pertanian/peternakan, kaki lima, pedagang di pasar, perbengkelan, salon kecantikan, ojek dan penjahit; kedua, dalam kaitannya dengan upaya mengentaskan kemiskinan, GPdl Elroi dan GPdl Elshaddai Wamena sangat peduli pelayanan terhadap kaum marginal, miskin dan terbelakang. Pelayanan ini dilakukan secara berkala bukan saja di seputaran kota Wamena, tetapi 
juga di pinggir kota hingga di luar kota dan bahkan di balik gunung di Kabupaten Jayawijaya dan Kabupaten lainnya di Pegunungan Tengah Papua. Bentuk kepedulian bermacam-macam, seperti; pelayanan kaum wanita, pelayanan pemuda, bantuan bahan kebutuhan pokok, membangun sekolah dan tempat-tempat ibadah. Semua pelayanan dimaksud, tidak terlepas dari kepedulian gereja atas dukungan jemaat terutama dari sisi materi dan finansial.

\section{DAFTAR PUSTAKA}

BPS Kabupaten Jayawijaya. (2018). Data Angka Kemiskinan di Jayawijaya 2018. Wamena: BPS Kabupaten Jayawijaya.

BPS Propinsi Papua. (2018). Keadaan Kemiskinan di Provinsi Papua. Jayapura: BPS Propinsi Papua.

Creswell, J. W. (2016). pendekatan Metode Kualitatif, kuantitatif, dan Campuran (Vol. 3). https://doi.org/https://doi.org/10.3929/ethz-b000238666

IImi, S. (2018). Konsep Pengentasan Kemiskinan Perspektif Islam. AlMaslahah Jurnal IImu Syariah, 13(1), 67. https://doi.org/10.24260/ almaslahah.v13i1.918

Julianto, Si. (2017). Kewirausahaan Jemaat: Sebuah Alternatif Berteologi. WASKITA, Jurnal Studi Agama Dan Masyarakat, 151-183.

Landyanto, E. A. (2014). Strategi Alternatif Penanggulangan Kemiskinan di Papua Melalui Pengembangan Keuangan Mikro.

Malik, A., \& Mulyono, S. E. (2017). Pengembangan Kewirausahaan Berbasis Potensi Lokal melalui Pemberdayaan Masyarakat. Journal of Nonformal Education and Community Empowerment, 1(1), 87-101. https://doi.org/10.15294/pls.v1i1.15151

Nugroho, F. J. (2019). Gereja dan Kemiskinan: Diskursus Peran Gereja di Tengah Kemiskinan. Evangelikal: Jurnal Teologi Injili Dan Pembinaan Warga Jemaat, 107-109. 
Purwanto, A., Erwan, \& Sulastyastusi, D. (2007). Metode Penelitian Kuantitatif, untuk Administrasi Publik, dan Masalah-masalah Sosial. Yogyakarta: Gava Media.

Risviantika, Wulandari, K., \& Evi. (2017). Pengentasan Kemiskinan MeIalui Kewirausahaan: Tinjauan Teoretis dalam Pendekatan Strenght Prespektif. Seminar Nasional Manajemen Dan Bisnis Ke-3. Jember: Program Studi Manajemen Fakultas Ekonomi dan Bisnis Universitas Jember.

Sudijono, A. (2010). Pengantar Statistik Pendidikan. Jakarta: PT Raja Grasindo Persada.

Sukirman, S. (2017). Jiwa Kewirausahaan dan Nilai Kewirausahaan Meningkatkan Kemandirian Usaha melalui Perilaku Kewirausahaan. Jurnal Ekonomi Dan Bisnis, 20(1), 117. https://doi.org/10.24914/ jeb.v20i1.318

Wahyu, T. (2009). Kemiskinan dan Bagaimana Memeranginya. Jurnal Ekonomi Dan Bisnis, 4(7), 56-65. 